\title{
STAKE EVALUATION MODEL (COUNTENANCE MODEL) IN LEARNING PROCESS BAHASA INDONESIA AT GANESHA UNIVERSITY OF EDUCATIONAL
}

\author{
Dewantara, I Putu Mas \\ Pendidikan Bahasa dan Sastra Indonesia, FBS, Undiksha \\ e-mail: mas.dewantara@gmail.com
}

\begin{abstract}
The evaluation study aimed to describe the implementation of Bahasa Indonesia as character development subject (Matakuliah Pengembangan Kepribadian/MPK) seen from (1) the learning plan, (2) the implementation of learning, and (3) evaluation of learning. Evaluation model used was a stake evaluation model (Countenance Model). Data were analyzed by descriptive-quantitative. The data were collected by using questionnaire, interview, and documentation. Categorization percentage is divided into five criteria, namely excellent (> 80\%), good (60\%-80\%), fairly good (40\%-60\%), poor $(20 \%-40 \%)$, and very poorly $(<20 \%)$. The research was conducted in the first semester of the academic year 2015/2016 with the sample of 315 students. The results showed that in general the Bahasa Indonesia as character development subject was categorised as good with the percentage of $71.02 \%$, in detail, the result can be described as follows: (1) the learning plan is categorized as good with the percentage of $72.62 \%$, (2) the implementation of learning is categorized as good with the persentage of $69.85 \%$, and (3) evaluation of learning activities is categorized as good with the persentage of $70.59 \%$. The implications of this research for lecturers is a need for efforts to sustain the implementation of learning that has been good even working on improving and working to improve elements of learning activities that have not been considered good. The results of the study suggest that regular evaluation needs to be done to get a better picture of evaluation with a larger number of sample. Another suggestion that can be proposed is the evaluation of learning by using a variety of evaluation model to get a better result of the learning Bahasa Indonesia.
\end{abstract}

Keywords: evaluation of learning, stake model (Countenance Model), Bahasa Bahasa Indonesia as character development subject (MPK)

\section{INTRODUCTION}

In any educational level, preparing human resources is always followed by the personality development of students. For example, in Ganesha Education University (UNDIKSHA) there are a number of subjects incorporated in the course of personality development (MPK) devoted to personalities that can develop as expected. One of the subjects was Bahasa Indonesia (Bahasa Indonesia Language). Inclusion of Bahasa Indonesia as a personality development course referring to National Law No. 2 of 1989 on National Education System and reaffirmed in National Law Number 20 Year 2003 on National Education System. In the Decree of the Director General of Higher Education Ministry of National Education number 323 / U / 2000 on Guidelines for Curriculum Development and Assessment of Higher Education Learning Outcomes, 
Bahasa Indonesia is one of thr subject of Personality Development (MPK) together with Religious Education and Civic Education.

UNDIKSHA as one of the state universities in Indonesia which enters Bahasa Indonesia as personality development courses that emphasize the use of Bahasa Indonesia in scientific work (writing) and the use of Bahasa Indonesia in scientific forums (oral). This is certainly in line with the opinion of Syiahbuddin (2006,p.2-3) saying that the general competence and specialized competence in teaching Bahasa Indonesia as personal development course in universities, are (1) general competence: students are able to express their thoughts and ideas effectively, efficiently, and communication in scientific writing, reports, letters, proposals, and capable of oral language in spoken language spontaneously or planned; (2) Specific competencies: a knowledgeable student of adequate and feel proud about the meaning, history, status, function of Bahasa Indonesia; able to explain the characteristics of scientific variety of language and apply them in academic performance; able to read the writing critical for the purposes of scientific and academic activities; able to explain the characteristics of academic papers, articles, reports, proposals, official letters, and speech practice, effective, efficient, and communicative discussion; apply the process of writing scientific papers, articles, reports, proposals, official letters, and speeches by the standard variety; apply scientific presentations perocedure in an effective and attractive in formal situations; and skilled scientific presentations with multimedia.

To be able to know how effective the implementation of the course requires evaluation. Evaluation or assessment is to determine the achievement of the goals of a program. Assessment is a form of test system in learning the skills to know how far the student has mastered the basic competencies that have been selected and assigned by the lecturer in learning. With the assessment can be obtained accurate information about the organization of teaching and learning success of students is measured and reported based on the achievement of certain competence (Hamalik, 2003,p. 55). During this unprecedented evaluation of learning Bahasa Indonesia in Undiksha. The evaluation conducted in Bahasa Indonesia course covers the planning, implementation of learning and evaluation. Therefore, the evaluation model used in this study is the Stake evaluation model. The results of the study is useful as an evaluation and reflection on the learning that has been carried out and also as a material consideration in planning future learning activities.

\section{METHODS}

This study is a descriptive evaluative research with a quantitative approach. Evaluation model used is Stake model evaluation stating that the emphasis on the evaluation of two types of operations, the description of these and distinguish three phases in the evaluation of the program, namely preparation, process, and outcomes. This model was chosen because the researcher wanted to know the implementation of learning in terms of planning, implementation, and outcomes that correspond to the model stake.

This study population was 1472 people, with the sample of 315 people. The sampling technique in this study was cluster random sampling: a sampling technique with subjects taken from each subpopulation equally and randomly.

Data collection techniques used is by administering a questionnaire with percentage descriptive analysis techniques. Test the validity of the instruments used is 
the external validity by using Product Moment Correlation. Meanwhile, instrument reliability was determined by Cronbach's Alpha formula. Data collection techniques used were observation and documentation. The data collected from the observation sheet and documentation were used as supportive data from the results obtained through the questionnaire technique. Data analysis technique used is descriptive analysis by percentage. Categorization percentage is divided into five criteria: excellent $(>80 \%)$, good $(60 \%-80 \%)$, fairly good $(40 \%-60 \%)$, unfavorable $(20 \%-40 \%)$, and very poor ( $<20 \%)$.

\section{FINDINGS AND DISCUSSION}

The data obtained in this study is the data obtained by various data collection methods include questionnaires, observation, and documentation. Related to the above, the results of the questionnaire is the most important primary data for a major part of the data analysis activities, whereas the results of documentation and observation are the supporting data used for conducting research in the field.

The form of the questionnaire used in this study was an enclosed questionnaire. The questionnaire consisted of 46 statements that describe the implementation of learning Bahasa Indonesia. This questionnaire was prepared by a blueprint with a fivepoint scale option, consisting of always, often, sometimes, raely, and never that can only be answered in accordance with the real situation on the ground. In addition, the observation sheet used in the form formatting tools for performance evaluation of teachers / lecturers. From the results of the data obtained trough documentation of the syllabus course, lesson plan, the students' scores, as well as photo documentation of research implementation.

Evaluation of the implementation of Bahasa Indonesia in the academic year 2015/2016 consisted of three components, namely planning / preparation of learning, the learning process implementation, and evaluation. This is consistent with Stake evaluation model that focuses on the implementation of the two main things, namely (1) description, and (2) judgments, and distinguishes three stages in the evaluation of the program, namely (1) antecedents, (2) the transaction, and (3) output.

The representation of student assessment into the planning, implementation and evaluation the overall learning can be seen in the following table.

Table 1. Assessment of Student of Planning, Implementation, and Evaluation of Learning conducted by Lecturer

\begin{tabular}{lcc}
\hline Sub Evaluation & Average (\%) & Category \\
\hline Plan & 72.62 & Good \\
Implementation & 69.85 & Good \\
Evaluation & 70.59 & Good \\
\hline TOTAL & 71.02 & Good \\
\hline
\end{tabular}

Table 1 shows that in general the implementation of the three components of Bahasa Indonesia course according to student assessment is quite good with the socre of $71.02 \%$. Data from the result can be explained as follows. 
1. The Planning of Bahasa Indonesia course

Evaluation of the learning plan or preparation (antecedent) learning undertaken by teachers and students is the early stage that describes the condition of learning. Evaluation of the learning plan in this study includes several indicators, namely:

a) Plan the management of learning activities

b) Plan organizing study materials (materials, media, and learning resources)

c) Plan of classroom management

d) Plan learning achievement assessment

The four indicators were translated into 10 questions that described the planning or preparation of the evaluation of learning. The questionnaire was distributed to 315 students. The results of the evaluation data can be summarized as follows.

Table 2. Data Evaluation of Education Planning

\begin{tabular}{llcl}
\hline No. & Lesson Planning Indicators & $\begin{array}{c}\text { Average } \\
\mathbf{( \% )}\end{array}$ & Category \\
\hline 1. & Plan the management of learning activities & 72.55 & Good \\
2. & $\begin{array}{l}\text { Plan organizing study materials (materials, } \\
\text { media, and learning resources) }\end{array}$ & 73.16 & Good \\
3. & Plan of classroom management & 71.87 & Good \\
4. & Plan learning achievement assessment & 72.63 & Good \\
\hline & Total & 72.62 & Good \\
\hline
\end{tabular}

Table 2 shows that in general the planning/preparation MPK learning Bahasa Indonesia in the 2015/2016 first semeser go well with an average score of $72.62 \%$. The table shows that the faculty has developed the syllabus, lesson plan, and handouts in implementing Bahasa Indonesia course. Lecturers have prepared the document in advanced, both in written and spoken form. Lecturer reiterated learning plan implemented at each meeting. Here are described in more detail on the results of the evaluation of the planning phase of learning.

Tabel 3. Data Evaluasi Perencanaan Pembelajaran Berdasarkan Sub-Indikator

\begin{tabular}{|c|c|c|c|}
\hline No. & Learning Planning & $\begin{array}{l}\text { Average } \\
(\%)\end{array}$ & Category \\
\hline 1. & Lecturer deliver lesson plans in each meeting & 72.06 & Good \\
\hline 2. & $\begin{array}{l}\text { Lecturer presents the objectives to be } \\
\text { achieved in each meeting }\end{array}$ & 72.44 & Good \\
\hline 3. & $\begin{array}{l}\text { Lecturers explain the basic competencies to } \\
\text { be taught }\end{array}$ & 73.14 & Good \\
\hline 4. & $\begin{array}{l}\text { Lecturer directing of learning resources that } \\
\text { will be used for the readiness of students } \\
\text { following study }\end{array}$ & 72.25 & Good \\
\hline 5. & $\begin{array}{l}\text { Lecturers plan and utilize a variety of learning } \\
\text { resources available }\end{array}$ & 73.14 & Good \\
\hline 6. & Lecturers prepare instructional media & 74.10 & Good \\
\hline 7. & $\begin{array}{l}\text { Lecturer check the completeness of students } \\
\text { in each lesson }\end{array}$ & 70.79 & Good \\
\hline 8. & $\begin{array}{l}\text { Lecturer check the completeness and } \\
\text { readiness classroom learning }\end{array}$ & 72.95 & Good \\
\hline
\end{tabular}




\begin{tabular}{llll}
\hline 9. & $\begin{array}{l}\text { Lecturers explain the evaluation techniques to } \\
\text { be used in learning }\end{array}$ & 73.21 & Good \\
10. $\begin{array}{l}\text { Lecturers explain the execution time } \\
\text { evaluation of learning }\end{array}$ & 72.06 & Good \\
\hline
\end{tabular}

2. Learning Implementation Bahasa Indonesia MPK

Learning activity is the implementation of lesson plans that have been prepared. The learning activities is a process containing a series of activities of teachers and students on the basis of reciprocal relationships that take place in an educational situation in order to achieve certain goals. Evaluation of the implementation or process (transaction) This study covers aspects of learning approaches, strategies and tactics in learning, teaching methods and techniques, as well as the learning procedure. Evaluation of the implementation / learning process in this study includes several indicators, namely:

a) Manage the space, time, and learning facilities

b) Using the strategies and methods of learning

c) Knowing mastery learning materials

d) Use of resources or instructional media

e) Manage classroom interaction

f) Provision of duty

g) Provision of feedback

There are 28 questions prepared by seven indicators. These questions illustrate the implementation of Bahasa Indonesia course held. Adapaun the evaluation result of the implementation phase of learning based on these indicators is as follows.

Table 4. Data Evaluation of Learning Implementation

\begin{tabular}{llcc}
\hline No. Indicators Learning Implementation & $\begin{array}{c}\text { Average } \\
\mathbf{( \% )}\end{array}$ & Category \\
\hline 1. & $\begin{array}{l}\text { Manage space, time, and facilities } \\
\text { learning }\end{array}$ & 67.86 & Good \\
2. & $\begin{array}{l}\text { Using the strategies and methods of } \\
\text { learning }\end{array}$ & 67.02 & Good \\
3. & Knowing mastery learning materials & 74.60 & Good \\
4. & Use of resources or instructional media & 73.21 & Good \\
5. & Manage classroom interaction & 70.68 & Good \\
6. & $\begin{array}{l}\text { Provision of duty } \\
\text { 7. }\end{array}$ & 71.83 & Good \\
\hline & Total & 69.85 & Good \\
\hline
\end{tabular}

Table 4 shows that the general implementation of Bahasa Indonesia course going well with the percentage of $69.85 \%$. Each indicator of the stage of implementation of learning also showed good category. Which has been planned by the lecturer seems to have been carried out in accordance with the plans that have been prepared. Evaluation data at the implementation stage of learning the details shown in the following table. 
Table 5. Data Evaluation of Sub-Based Learning Implementation Indicators

\begin{tabular}{|c|c|c|c|}
\hline No. & Sub-indicators Learning Implementation & $\begin{array}{l}\text { Average } \\
(\%)\end{array}$ & Category \\
\hline 1. & $\begin{array}{l}\text { Lecturer asks student's readiness for } \\
\text { receive lessons at each meeting }\end{array}$ & 74.41 & Good \\
\hline 2. & $\begin{array}{l}\text { Lecturer asks the materials that have been } \\
\text { passed to students in early learning }\end{array}$ & 70.22 & Good \\
\hline 3. & $\begin{array}{l}\text { Lecturer conducts exploratory activities } \\
\text { (debriefing/scratch test) to students about the } \\
\text { material to be studied }\end{array}$ & 68.06 & Good \\
\hline 4. & Lecturer timely starts and ends to learning & 58.73 & $\begin{array}{l}\text { Fairly } \\
\text { good }\end{array}$ \\
\hline 5. & $\begin{array}{l}\text { Lecturer teaching methods are varied so that the } \\
\text { learning is not boring }\end{array}$ & 63.94 & Good \\
\hline 6. & $\begin{array}{l}\text { Lecturers uses demonstration method to clarify } \\
\text { the delivery of learning materials }\end{array}$ & 63.37 & Good \\
\hline 7. & $\begin{array}{l}\text { Lecturer strives for the learning process takes } \\
\text { place in a pleasant atmosphere }\end{array}$ & 59.87 & $\begin{array}{l}\text { Fairly } \\
\text { good }\end{array}$ \\
\hline 8. & $\begin{array}{l}\text { Lecturer strives for the learning process takes } \\
\text { place in a pleasant atmosphere }\end{array}$ & 80.89 & Good \\
\hline 9. & $\begin{array}{l}\text { Lecturer delivers material with interesting and } \\
\text { easily understood }\end{array}$ & 73.14 & Good \\
\hline 10. & $\begin{array}{l}\text { Lecturers explains the material using spoken and } \\
\text { written language is clear and easy to understand }\end{array}$ & 77.14 & Good \\
\hline 11. & $\begin{array}{l}\text { Lecturers explains the material coherently from } \\
\text { the easiest to the most difficult }\end{array}$ & 73.52 & Good \\
\hline 12. & $\begin{array}{l}\text { Lecturers uses appropriate learning media to } \\
\text { clarify the material presented }\end{array}$ & 71.49 & Good \\
\hline 13. & $\begin{array}{l}\text { Lecturers uses one of the sources of the book as a } \\
\text { reference in learning }\end{array}$ & 74.79 & Good \\
\hline 14. & $\begin{array}{l}\text { Lecturers uses other learning resources in } \\
\text { addition to reference books that are relevant to } \\
\text { the material }\end{array}$ & 73.33 & Good \\
\hline 15. & $\begin{array}{l}\text { Lecturers gives students an opportunity to ask } \\
\text { those who have clear }\end{array}$ & 75.37 & Good \\
\hline 16. & $\begin{array}{l}\text { Lecturer goes around approaching students to } \\
\text { monitor student progress in learning }\end{array}$ & 58.92 & $\begin{array}{l}\text { Fairly } \\
\text { good }\end{array}$ \\
\hline 17. & $\begin{array}{l}\text { Lecturer exhibits behaviors that patience and not } \\
\text { get upset when the students experienced an error }\end{array}$ & 74.10 & Good \\
\hline 18. & $\begin{array}{l}\text { Lecturer monitors each student, whether the } \\
\text { student is actually able to do what has been } \\
\text { instructed }\end{array}$ & 71.94 & Good \\
\hline 19. & $\begin{array}{l}\text { Lecturer treats students fairly regardless of race, } \\
\text { religion, race and social status }\end{array}$ & 70.60 & Good \\
\hline 20. & $\begin{array}{l}\text { Lecturers are able to create an intimate } \\
\text { relationship }\end{array}$ & 73.14 & Good \\
\hline 21. & $\begin{array}{l}\text { Lecturer gives the assignment in accordance with } \\
\text { the basic competencies that are taught }\end{array}$ & 73.33 & Good \\
\hline
\end{tabular}




\begin{tabular}{|c|c|c|c|}
\hline 22. & $\begin{array}{l}\text { Lecturer gives the assignment at the end of each } \\
\text { lesson }\end{array}$ & 59.43 & $\begin{array}{l}\text { Fairly } \\
\text { good }\end{array}$ \\
\hline 23. & Lecturer gives a test at the end of each lesson & 58.48 & $\begin{array}{l}\text { Fairly } \\
\text { good }\end{array}$ \\
\hline 24. & Lecturer commissions a friend to work in groups & 72.06 & Good \\
\hline 25 & Lecturer gives back task that has been corrected & 74.03 & Good \\
\hline 26. & $\begin{array}{l}\text { Lecturer asks the students to make a summary of } \\
\text { the learning material studied }\end{array}$ & 66.67 & Good \\
\hline 27. & $\begin{array}{l}\text { Lecturer responds to comments the students well } \\
\text { and provide an explanation of relevant }\end{array}$ & 70.79 & Good \\
\hline \multirow[t]{2}{*}{28.} & $\begin{array}{l}\text { Lecturers provides feedback (comments) to tasks } \\
\text { that have been undertaken students }\end{array}$ & 74.16 & Good \\
\hline & Total & 69.85 & Good \\
\hline
\end{tabular}

Table 5 regarding the evaluation of learning based on sub-indicators showed that the general implementation of learning in both categories. There are several sublearning in good enough category, namely the sub- (1) lecturer timely start and end of learning, (2) faculty to strive for the learning process takes place in an atmosphere of explaining, (3) lecturers around approaching students monitor the progress of students in learning, (4) the lecturer gives the assignment at the end of each lesson, and (5) the lecturer giving tests at each end of the lesson.

3. Evaluation of Bahasa Indonesia course

Evaluation is an important part of learning. Through the evaluation can be determined whether or not a learning or the implementation or otherwise of a learning purpose. The evaluation of the assessment / learning outcomes in this study includes several indicators, namely:

a) Carry out the assessment of learning

b) Assessment of student behavior in learning

c) Clarifying learning outcomes

Three indicators are then translated into 8 statements that describe the assessment/evaluation of learning outcomes in the learning process. The results of the evaluation of the three indicators are as follows.

Table 6. Evaluation of Event Data Learning Evaluation

\begin{tabular}{llcc}
\hline No. & Learning Evaluation Indicators & $\begin{array}{c}\text { Average } \\
(\mathbf{\%})\end{array}$ & Category \\
\hline 1. & Carry out the assessment of learning & 70.48 & Good \\
2. & Assessment of student behavior in learning & 73.59 & Good \\
3. & Clarify learning outcomes & 68.70 & Good \\
\hline & Total & 70.59 & Good \\
\hline
\end{tabular}

Based on Table 6 above data showed that in general the evaluation of Bahasa Indonesia course quite well with the percentage of $70.59 \%$. Lecturer in addition has assessed learning outcomes and behaviors of students in learning, has also clarified the results of student learning well. To know the evaluation of learning which has been done by lecturer in more detail can be seen in the following table. 
Table 7. Data Evaluation of Activity Based Learning Evaluation Sub-Indicators

\begin{tabular}{|c|c|c|c|}
\hline No. & Sub-indicators Evaluation of Learning & $\begin{array}{c}\text { Average } \\
(\%)\end{array}$ & Category \\
\hline 1. & $\begin{array}{l}\text { Lecturer makes an assessment of the ability } \\
\text { of students in the learning process }\end{array}$ & 76.00 & Good \\
\hline 2. & Lecturer does research on a given task & 64.00 & Good \\
\hline 3. & $\begin{array}{l}\text { Lecturer makes an assessment at the end of } \\
\text { basic competencies that are taught }\end{array}$ & 71.43 & Good \\
\hline 4. & $\begin{array}{l}\text { Lecturer assesses students in the discipline of } \\
\text { collecting a given task }\end{array}$ & 71.87 & Good \\
\hline 5. & $\begin{array}{l}\text { Lecturer assesses students who actively ask } \\
\text { or answer in the learning process }\end{array}$ & 75.30 & Good \\
\hline 6. & $\begin{array}{l}\text { Lecturer presents the results of evaluation of } \\
\text { learning both pretest, posttest, tasks, UTS, } \\
\text { UAS, transparently }\end{array}$ & 76.70 & Good \\
\hline 7. & $\begin{array}{l}\text { Lecturer discusses the results of student work } \\
\text { or the results of the test in front of the class }\end{array}$ & 70.22 & Good \\
\hline \multirow[t]{2}{*}{8.} & $\begin{array}{l}\text { Lecturer does a remidial for students who } \\
\text { have not completed at each basic competence }\end{array}$ & 59.17 & $\begin{array}{l}\text { Fairly } \\
\text { good }\end{array}$ \\
\hline & Total & 70.59 & Good \\
\hline
\end{tabular}

Table 7 on evaluation of Bahasa Indonesia course at the implementation stage study evaluation were reviewed by sub-sub shows no one is quite good, namely in subeight (lecturer remidian held for students who have not completed at each basic competence). Meanwhile, another sub-categories of the evaluation indicates the learning takes place in both categories.

\section{DISCUSSION}

The data in Table 1 show that Bahasa Indonesia course take place in good category $(71.02 \%)$ with the details of that (1) planning of the learning takes place in either category $(72.62 \%),(2)$ the implementation of the learning takes place in either category $(69.85 \%)$, and (3) evaluation of the learning takes place in either category $(70.59 \%)$. To be more clear about the planning, implementation, and evaluation of Bahasa Indonesia course described as follows.

\section{Planning Bahasa Indonesia course}

Learning evaluation data shows that the planning activities of Bahasa Indonesia Course goes well. Judging from the indicators and existing sub- seen that all the indicators and sub- are the subject of evaluation has been going well, as shown in Table 2 and Table 3. Lecturer planned well in (1) learning activities, (2) the organization of materials (materials, media , and learning resources), (3) classroom management, and (4) assessment of learning outcomes. This is in line with those expressed by Salirawati (2005) that a good educator at the planning stage of learning should be set up (1) 
learning objectives, (2) teaching materials, (3) teaching methods, (4) media, and (5) evaluation,

The results also show that the lecturers have been properly made preparations regarding (1) the lesson plan at each meeting, (2) the objectives to be achieved in every meeting, (3) basic competencies to be taught, (4) learning resources that will be used to readiness of students following study, (5) use a variety of learning resources available, (6) media, (7) various completeness learning, (8) the readiness classroom learning, (9) evaluation techniques to be used in learning, and (10) the execution time evaluation. Majid (2011) says that a good educator must have the competence (1) capable of describing the purpose / learning competencies; (2) being able to select or specify the material; (3) capable of organizing the subject matter; (4) able to determine the method or learning strategies; (5) capable of determining the learning resources / media / props learning; (6) able to prepare the assessment of learning; (7) able to determine valuation techniques; and (8) is able to allocate time learning well. The results showed that competence as submitted by Majid in line with the indicators and sub- used in this study, so it can be said that the competent educators criteria as presented by Majid had been met by the lecturer of the Bahasa Indonesia course.

\section{Learning Implementation Bahasa Indonesia MPK}

Implementation of learning is the stage of implementation of lesson plans that had been developed previously. The essence of the implementation phase is the operational activities of learning itself. One of the aspects that affect the learning success is the ability of educators to manage learning, in the process, the management should be geared up to be a process of meaningful and conducive to the formation of students' abilities. Therefore, in addition to learning activities developed systematically, effectively and efficiently also need variety of activities as an alternative to cultivate motivation and students in learning activities.

The study, of the seven indicators of the implementation of the learning process, namely (1) managing space, time, and learning facilities, (2) teaching methods, (3) control of learning materials, (4) the use of sources / media, (5) the management of interaction class, (6) the provision of duty, and (7) providing feedback has been taking place in both categories (69.87\%). However, judging from the sub-categories, there are five sub-category with good enough category, namely the sub-indicator: (1) lecturer timely start and end of learning, (2) the lecturer encourage to make the learning process that takes place in an atmosphere of explaining, (3) lecturers monitor developments by going around the classroom to check the the students, (4) the lecturer gives the assignment at the end of each lesson, and (5) the lecturer gives tests at each end of the lesson.

There are some situations or obstacles that lead to the evaluation at the level of the sub-categories which are pretty good. First, regarding the timeliness of lecturers in the start and end of study. Lecturers recognize that this may happen due to several reasons such as for their seminars, civil cervices, meetings, and other activities that cause a conflict of time so that the lecturer started a little slow or terminate learning sooner than the stipulated time. The limited number of lecture room is also a factor. This situation resulted in the lecturer had to wait some time before informing students of the lecture room. If so, you can bet the lecture did not go according to the planned time.

Second, regarding the efforts lecturer in creating a pleasant atmosphere. Recognition from this lecturer to this situation is it has encouraged to use various 
strategies to create a pleasant atmosphere. However, sometimes learning became tense when students were asked to show their skills to communicate in public. Third, regarding the activities of the lecturer in the classroom going around in monitoring the progress of students. Lecturer acknowledged that the monitoring has been carried out, only in some lecture classroom, it is very difficult to monitor each student by doing that. This occurs because there is a small room with the big number of students, so walking around is very difficult.

Fourth, regarding giving homeworks at the end of the lesson. some lecturers acknowledge that there is always a given task at the end of each meeting. However, some other states do not give it in routine. Given assignment was varied, there was in the form of writing or reading assignment of resources for discussion at the next meeting. Fifth, regarding the provision of a test at the end of learning. Results of interviews with the lecturers showed that most professors do not provide routine assessment at the end of the meeting. Most lecturers also acknowledged that the test given at the end of learning more shaped oral test.

\section{Evaluation of Bahasa Indonesia course}

Evaluation of the learning process is a process to collect, analyze, and interpret information to determine the level of achievement of learning objectives. The results showed that the evaluation of Bahasa Indonesia course has been going well, that on learning assessment indicators, assessment of student behavior, and the clarification of learning outcomes. This means that the lecturers have been put through the assessment of learning, assessment of student behavior, and clarifying the results of learning well. When examined in more detail, in general sub-evaluation of learning in both categories. Only one sub-category was categorized quite good, namely the sub-indicator "lecturer gives remidial for students who have not completed at each basic competence". Results of interviews with lecturers showed that most of the lecturers did not conduct remedial to students. Students who did not pass the course are those who have low values below the value that has been set out in the applicable procedures for assessment at UNDIKSHA. Considerations such as the activity and presence also made by the lecturer before the final scores on college campuses.

The findings show that the assessment of learning outcomes that do not solely concerns the evaluation of learning outcomes, but also pay attention to the evaluation of the learning process. Assessment process can shows ratings of attitudes and behavior of students in each lesson. Lecturers also assess student discipline in assignments, assessing acivity in the classroom. This assessment is often called the affective ratings. In cognitive and psychomotor, lecturers assess students' ability in the form of assessment practices and tasks given.

\section{CONCLUSIONS}

Based on the results of research and discussion on the evaluation of the implementation of Bahasa Indonesia course, it is concluded that learning has taken place with the category of good $(71.02 \%)$, with details (1) the activities of planning the learning was implemented well with the percentage of $72.62 \%$, (2) the activities of the implementation of learning was implemented well with the percentage of $69.85 \%$, and (3) the evaluation of learning activities have also been carried out well with the percentage of $70.59 \%$. From the results it is suggested that this research can be 
evaluated periodically to get an idea of a better evaluation with a larger number of samples.

\section{REFERENCES}

Depdikbud. (1998). Undang Undang RI Nomor 2. Tahun 1989 Tentang Sistem Pendidikan Nasional. Jakarta: Depdikbud.

Hamalik, Oemar. (2003). Kurikulum dan Pembelajaran. Jakarta: Bumi Aksara.

Majid, Abdul. (2011). Perencanaan Pembelajaran: Mengembangkan Standar Kompetensi Guru. Bandung : PT. Remaja Rosdakarya Offset.

Pemerintah Republik Indonesia. (2003). Undang-Undang Republik Indonesia No.20 Tahun 2003 tentang Sistem Pendidikan Nasional. Jakarta

Salirawati, Das. (2005). "Persiapan Pembelajaran". Makalah disampaikan dalam Workshop Strategi Pembelajaran Mahasiswa Jurusan Tadris Fakultas Tarbiyah UIN Sunan Kalijaga di PPPG Kesenian pada tanggal 14 Juni 2005. Dalam https://www.academia.edu/7871077/PERSIAPAN_PEMBELAJARAN.

Diakses Diakses 5 Juni 2015.

Surat Keputusan Direktur Jendral Perguruan Tinggi Departemen Pendidikan Nasional Nomor 323/U/2000 tentang Pedoman Penyusunan Kurikulum Pendidikan Tinggi dan Penilaian Hasil Belajar.

Syihabuddin. 2006. "Pembelajaran Bahasa Indonesia sebagai MPK Berbasis Kompetensi”. Jakarta: Direktorat Jenderal Pendidikan Tinggi Departemen Pendidikan Nasional. 